European journal of American studies

$16-4 \mid 2021$

The American Neuronovel (2009-2021)

\title{
Amnesia Narratives: Memory, Forgetting, and Identity
}

Jason Tougaw

\section{(2) OpenEdition}

\section{Journals}

Electronic version

URL: https://journals.openedition.org/ejas/17472

DOI: 10.4000/ejas. 17472

ISSN: 1991-9336

\section{Publisher}

European Association for American Studies

\section{Electronic reference}

Jason Tougaw, "Amnesia Narratives: Memory, Forgetting, and Identity", European journal of American studies [Online], 16-4 | 2021, Online since 20 December 2021, connection on 08 July 2022. URL: http:// journals.openedition.org/ejas/17472 ; DOl: https://doi.org/10.4000/ejas. 17472

This text was automatically generated on 8 July 2022.

\section{(c) (7) \&}

Creative Commons - Attribution-NonCommercial 4.0 International - CC BY-NC 4.0

https://creativecommons.org/licenses/by-nc/4.0/ 


\title{
Amnesia Narratives: Memory, Forgetting, and Identity
}

\author{
Jason Tougaw
}

\section{Introduction}

1 As Jonathan Lethem observes in his introduction to The Vintage Book of Amnesia, "Real, diagnosable amnesia-people getting knocked on the head and forgetting their namesis mostly just a rumor in the world. It's a rare condition, and usually a brief one. In books and movies, though, versions of amnesia lurk everywhere" (xiii). Lethem is differentiating outlandish or comical forms of literary amnesia, various forms of memory loss associated with a condition like Alzheimer's or certain brain injuriesparticularly retrograde amnesia, whereby a person loses memories already formed, and anterograde amnesia, whereby a person loses the ability to make new memories. In literature, film, and television, amnesia has a reputation as a cheap plot device that exaggerates and sensationalizes severe memory loss, often portraying forms of global transient amnesia, whereby a person loses all memory, but only temporarily.

Lethem's anthology demonstrates that amnesia is just as often a vehicle for literary innovation, philosophical exploration, psychological insight, and social critique. His collection includes amnesia fictions by twentieth-century writers: Shirley Jackson, Jorge Luis Borges, Vladimir Nabokov, Anna Kavan, Edmund White, and Haruki Murakami. It's a tradition with a long history, including William Shakespeare, Wilkie Collins, Daphne DuMaurier, Octavia Butler, and Jonathan Lethem himself. In that sense, amnesia fictions may be the most abundant precursors to the contemporary neuronovel. A cluster of recent, high-profile fiction and nonfiction amnesia narratives join a rapidly evolving tradition of neuronovels and brain memoirs, drawing on neuroscience to explore philosophical and social questions about the brain, identity, social relations, and history (Tougaw 5).

3 Maud Casey's The Man Who Walked Away (2013), winner of the 2015 St. Francis Literary Prize, fictionalizes a nineteenth-century case history about Frenchman Albert Dadas, 
whose fugue states propelled extraordinary walks across great swaths of Europe. Nobel laureate Kazuo Ishiguro's most recent novel, The Buried Giant (2015), imagines an AngloSaxon world in which collective amnesia produces political peace but leaves its protagonists searching for personal histories. Lethem makes the point that a fictional character has no memory, is "conjured out of the void by a thin thread of sentences" (xiv). So what cultural work does fictional amnesia do? The answer will vary, of course, but Casey's and Ishiguro's novel operate like philosophical thought experiments, portraying fictional-or hypothetical-scenarios in order to address difficult questions.

It's not quite true that amnesia is "just a rumor," though it is rare. In fact, the fictional techniques and ethical commitments of Casey's and Ishiguro's novels come into focus when they're understood in dialogue with nonfiction amnesia narratives and memory research. Like most neuronovels, Casey's and Ishiguro's fictions are engaged in urgent and unsettled debates about the brain and identity. They resonate with recent works of nonfiction documenting the lives of people with cases of severe, long-lasting and very real memory loss-including numerous short works by Oliver Sacks, Suzanne Corkin's Permanent Present Tense: The Unforgettable Life of the Amnesiac Patient H.M. (2013), and Alix Kates Shulman's memoir To Love What Is: A Marriage Transformed (2009). The result is literary exploration of psychological, neurological, philosophical, social, and ethical questions raised by both nonfiction accounts of amnesia and a history of memory research, particularly that which emphasizes the roles forgetting plays in the making of memories. All four texts share some notable elements: 1) They portray extreme instances of amnesia in order to explore philosophical and psychology questions about the role of forgetting in memory itself, 2) They offer detailed exploration of elements of identity that remain when memory is lost, and 3) They build worlds around their amnesiac characters, worlds designed to afford them respect, agency, and opportunities to express aspects of their identities that survive their failing memories.

5 As neuronovels, then, Casey's and Ishiguro's fictions explore questions about amnesia as well as more ordinary acts of forgetting that shape both memory and identity. For example, what techniques does a writer need to narrate the life story of an amnesiac? What aspects of identity remain when memory fails? If memory is not a single or even unified phenomenon, how do various types of memory-episodic, procedural, somatic, perceptual, affective-shape the contours of identity? What might we learn about memory and identity by crafting narratives that account for exceptional experiences rather than standard ones? How might fiction that portrays extreme forms of forgetting provoke dialogue about often overlooked questions about the central role forgetting plays in both psychology and culture? What social obligations arise with regard to people in the real world suffering from amnesia? How might family, loved ones, caregivers, the medical establishment, and researchers do a better job creating affordances that enable people with severe amnesia to express themselves or gain agency?

6 Lethem is not particularly interested in amnesia as a plot device, focusing instead on "fiction that, more than just presenting a character who'd suffered memory loss, entered into an amnesiac state at some level of the narrative itself-and invited the reader to do the same" (xvi). The works I'm discussing here are predated by two case histories about amnesiacs published by Oliver Sacks that initiate formal strategies for representing amnesia, "The Lost Mariner" (1984) and "The Abyss" (2007), both of which seek to describe what's lost and what remains of identity when severe memory loss 
transforms the lives of their subjects. Sacks is insistent that the devastation of amnesia makes it difficult to recognize remnants of identity, and that these remnants are keys to mitigating the suffering-or enhancing the lives-of amnesiacs.

7 In "The Lost Mariner," Sacks establishes a narrative pattern that reflects cultural assumptions about the equation of identity and memory. Jimmy, his subject, suffers from retrograde amnesia, a result of Korsakov's Syndrome. Sacks opens his essay with an epigraph from My Last Sigh: The Autobiography of Luis Buñuel (1983): "You have to begin to lose your memory, if only in bits and pieces, to realize that memory is what makes our lives. Life without memory is no life at all.... Our memory is our coherence, our reason, our feeling, even our action. Without it, we are nothing" (23). The epigraph is a narrative foil. The fragility of memory is terrifying to Buñuel. Nonetheless, in his memoir the surrealist is careful to acknowledge that memory blends with imagination -and that identity is a composition of "my errors and doubts as well as my certainties" (6). When Buñuel adds imagination to the equation, he hints at the idea that memory is not singular, either phenomenologically or physiologically. His "errors and doubts" are crucial to his identity.

8 The entanglement of memory with a variety of cognitive, somatic, and social phenomena is key to the narrative arc of Sacks's case. Towards the end, Sacks observes Jimmy in chapel: "I saw here an intensity and steadiness of attention and concentration that I had never seen before in him or conceived him capable of.... He was wholly held, absorbed, by a feeling. There was no forgetting, no Korsakov's then" (37). Sacks undoes Buñuel's equation between memory and identity. Instead, he suggests that memory and identity are entangled-with each other, with aesthetics, spiritual experience, attention, sociality, and other forms of mental experience. Sacks reproduces this narrative arc in "The Abyss," about musician Clive Wearing, whose amnesia results from a brain infection. Wearing's ability to express himself through music-listening, playing, and discussing it-prompts Sacks to differentiate his "episodic memory" from his "semantic memory" ("The Abyss: Music and Memory"). The result is that Wearing's suffering can be mitigated through musical experience, where he can express the semantic identity that outlives his autobiography. When Sacks proposes the idea that memory and identity are distributed and entangled phenomena, he opens a window onto possible social interventions that may alleviate the suffering of their subjectswhereas the idea that an amnesiac lacks identity leaves little room for engagement.

Written nearly three decades after "The Lost Mariner," Suzanne Corkin's Permanent Present Tense and Shulman's To Love What Is begin where Sacks leaves off-with an awareness that an ethical commitment to improving the lives of amnesiacs requires careful differentiation between memory and identity. Both narrate the life stories of men who experience severe forms of anterograde amnesia. Corkin writes as a memory researcher with a humane interest in her subject, and Shulman writes as a spouse with an urgent need to understand memory research. Their perspectives are complementary, their insights about memory remarkably similar. Both narratives are non-linear quests for discovery that entangle the past with the present in deliberate ways. Corkin tells the life story of Henry Molaison-known in the neurology literature as H. M.-with whom she worked for more than four decades, interrupting that narrative with accounts of milestones in the history of memory research. Shulman tells the story of her husband's adaptation to his amnesia and her own research about memory, interrupting that narrative with stories about the early days of their 
relationship. While these are very different books, the intimacy of the writers with their subjects leads to a keen understanding of the ways amnesiac identity may be expressed.

\section{Living with Amnesia} the scientific literature-ends with a bizarre scene, one where carefully researched nonfiction starts to feel, for all its basis in reality, like science fiction. Corkin, along with neuroscience luminaries V. S. Ramachandran and Larry Squire and philosophers Patricia and Paul Churchland, watch as Molaison's brain is dissected into 2,401 very thin slices, photographed with meticulous care and preserved for future research. Molaison died in Connecticut in 2008. Soon after his death, Corkin and a team of researchers conducted extensive MRI scanning of his brain, both while it was in his skull (in vivo) and after it had been excised (ex vivo)-again, with a group of witnesses looking on. Then it was transported to San Diego for dissection. Corkin narrates the clinical scene of the delicate operation after telling the story of decades of working with Molaison, as a research subject with whom she developed considerable intimacy. Like so many nonfiction narratives about people living with amnesia, her book emphasizes what Molaison's extreme experience of forgetting can teach us about the workings of more ordinary memories and makes the emphatic point that memory alone does not define identity. While Molaison's identity is altered radically by severe memory loss, he is a person with qualities who engages in relation with others. Any narrative about a person whose memory loss makes him a research subject must also grapple with the ethics of consent and the continuous temptation to sensationalize his experience the way so many works of fiction, film, and television do.

Corkin takes great care to ensure the legacy of Molaison's brain; her involvement with the physical organ about which so many memory researchers have theorized becomes part of the story of their intimate relationship. After Henry's death, his brain represents him:

For the cutting, the brain, embedded in its block of frozen gelatin, was secured on an electronic device, a microtome, which acted like an exceedingly precise meat slicer. To keep the brain cool, technicians pumped liquid ethanol through a tube into the surrounding spaces. Jacopo, wearing black gloves, sat in front of the microtome. Each pass of the blade over the block of ice revealed a delicate roll of brain tissue and gelatin, which he gently wiped up with a large, stiff paintbrush and placed in a well in a partitioned container that resembled an ice-cube tray, filled with solution. The front of Henry's brain faced upward, and a sixteen-megapixel camera mounted above captured and numbered each surface before it was cut. Each slice was placed in a well with the corresponding number. The cutting began at the front of the brain and proceeded back-from the frontal pole to the occipital pole. As exciting as the project itself was, the painstaking work of cutting and securing thousands of brain slices was monotonous. (301)

Were it not for their lifetime relationship, the image of Molaison's brain, facing upward as the microtome shaves slices, collected in a well of liquid, might appear merely clinical, or perhaps gothic. But Corkin's biography is the story of getting to know an amnesiac, through clinical work with him. Famously, Molaison became amnesiac after brain surgery, "bilateral medial temporal lobe resection, an experimental brain operation intended to alleviate the severe epilepsy he had faced since childhood" (xii). 
After the surgery, Molaison could remember much of the past, but he was unable to make new memories-at least, not lasting ones. As Eric Kandel, perhaps the best-known figure in memory research, observes, H. M. "had perfectly good short-term memory, lasting for minutes" and "perfectly good long term-memory for events that occurred before his surgery.... What H. M. lacked, and lacked to the most profound degree, was the ability to convert new short-term memory into long-term memory" (127).

For half a century, Molaison was a neurological celebrity: "Henry was famous, but did not know it. His striking condition had made him the subject of scientific research and public fascination. For decades I received requests from the media to interview and videotape him. Each time I told him how special he was, he could momentarily grasp, but not retain, what I had said" (xv). While Molaison did not retain explicit memory, Corkin maintains that "he gradually built up a sense of familiarity for me." They established an affective relationship through their clinical work together, and Corkin made a commitment to humanizing him and shaping his legacy:

Over the course of decades during which I worked with Henry, it became my mission to make sure he is not remembered just by brief, anonymous descriptions in textbooks. Henry Molaison was much more than a collection of test scores and brain images. He was a pleasant, engaging, docile man with a keen sense of humor, who knew he had a poor memory but accepted his fate. There was a man behind the data. Henry often told me that he hoped that research into his condition would help others live better lives. He would have been proud to know how much his tragedy has benefitted science and medicine. (xv)

When Corkin narrates the scenes during which Molaison's brain is scanned, removed, transported, dissected, photographed, and preserved after death, she creates a denouement for his biography that emphasizes the entanglement of "the data" and "the man behind it." Her relationship with him was defined by the data she'd been collecting for decades, and it becomes clear that an enduring clinical relationship is shaped by particular forms of intimacy: the rituals of repeated meetings, evolving but often very similar cognitive tests, and discussion of the scientific implications of the meetings. Corkin writes to contribute to the history of neuroscience, to propose theories of memories based on her work with Molaison, and to show, through narrative, that memory and identity are not synonymous-that aspects of identity remain when memory fails.

In his book Searching for Memory: The Brain, the Mind, and the Past (1997), Daniel Schacter synthesizes much of the same memory research as Kandel. In particular, Schacter emphasizes the importance of "retrieval cues" that stimulate the physiology of memory and account for the fragility and changeability of its phenomenology:

Because our understanding of ourselves is so dependent on what we can remember of the past, it is troubling to realize that successful recall depends heavily on the availability of appropriate retrieval cues. Such dependence implies that we may be oblivious to parts of our pasts because we fail to encounter hints or cues that trigger dormant memories. This may be one reason why encountering acquaintances we have not seen for years is often such an affecting experience: our old friends provide us with cues and reminders that are difficult to generate on our own, and that allow us to recollect incidents we would ordinarily fail to remember. (63)

16 Of course, in social relationships, people become retrieval cues for each other, each dependent on "the availability" of each other's memories. As Schacter stresses, all memory is a creative, constructive process: "Although it is often assumed that a 
retrieval cue merely arouses or activates a memory that is slumbering in the recesses of the brain, I have hinted at an alternative: the cue combines with the engram to yield a new, emergent entity-the recollective experience of the rememberer-that differs from either of its constituents" (70). In Schacter's model, an engram is a dynamic neurological imprint revised with each new recollection. With this in mind, the rituals of the relationships Corkin and Shulman recount become central to their amnesia narratives, which depict not only the failing memories of Molaison and Scott, but also the functional, but constructive memories of themselves as writers and narrators.

Like Corkin, Shulman emphasizes the physiology and phenomenology of memory in To Love What Is-very much in keeping with contemporary accounts of memory research by luminaries in the field Erick Kandel and Daniel Schacter. Kandel's book, In Search of Memory: The Emergence of the New Science of Memory (2006), is a hybrid memoir and history of memory research, weaving personal recollection with a synthesis of memory theory to demonstrate the kind of subjectivity that shapes Corkin's and Shulman's amnesia narratives. Kandel writes, "Explicit memory is highly individual. Some people live with such memories all the time. Virginia Woolf falls into this category. Her memories of childhood were always at the edge of consciousness" (280). For Henry Molaison and Shulman's husband Scott, explicit memory is also highly particular to their experiences. Both Corkin and Shulman are witnesses to its absence but also its flashes of presence. Kandel is contrasting explicit, conscious memory of lived events with implicit memories of habitual routines (sometimes called "procedural memory"). Corkin and Shulman emphasize the "highly individual" dynamics of explicit and implicit memory that shape their relationships with Henry and Scott. Molaison talks about his past and experiences fleeting awareness of his relationship with Corkin. Scott's memory of his relationship with Shulman seems to deteriorate with time, but returns at unexpected moments.

Corkin's goals are personal, ethical, and theoretical. As she writes, "it became my mission to make sure that [Molaison] is not remembered just by brief, anonymous descriptions in textbooks" (xv). Shulman's perspective is even more personal, of course, because she's looking for a way to help her husband Scott live a meaningful life after his accident: "In our marriage, if we should go our separate ways, his way would be directly to a nursing home. This man... is too dear to me to be able to contemplate that now" (103). Not surprisingly, the voices of these two writers follow from their relationships with their subjects. Corkin's is humanely clinical, and Shulman's is urgently compassionate. Despite the differences, Corkin's and Shulman's insights about memory and identity are often quite similar. They focus on personality traits, affective experiences, and intact memories that shape the identities of their amnesiac subjects.

Corkin observes that Molaison played a key role in the history of memory research after a bilateral medial temporal lobectomy intended to alleviate symptoms of severe epilepsy: "We have learned-initially from Henry-that memory does not reside in one spot in the brain. Instead, memory engages many parts of the brain in parallel." She explains that

Our research with Henry focused on two kinds of investigation. One used brainimaging tools to reveal the anatomy of his surgery and thereby show exactly what had been removed and what had been left behind. This level of detail is critical when neuroscientists are trying to relate the function in discrete areas to specific behaviors. The other kind of study harnessed cognitive tests to evaluate Henry's memory and other intellectual functions. (77) 
brain scans investigated Molaison's brain and the cognitive tests his experience. Both contribute to Corkin's relationship with him. She describes Molaison as "an agreeable subject," one who "was not claustrophobic inside the scanner," but also one who "was a gourmand," enjoying lunch with researchers after the sessions. As she writes, "my colleagues at the imaging center were always eager to have a conversation with him, so he often attracted a small group of fans. But he never questioned why he was such an attraction, taking it all in stride" (81). The combination of clinical distance and personal intimacy Corkin describes creates pathos and narrative tension. There is no doubt that within the parameters of research protocols, Molaison was treated with the utmost care and with his family's consent. Nonetheless, Corkin's description recalls a history of medical objectification of people who cannot consent-the displays of early modern operating theaters, tours of London's notorious Bedlam (or Bethlehem Royal Hospital) asylum, Charcot's demonstrations of his hypnotic techniques on so-called "hysterical women." Corkin goes so far as to suggest that "Using MRI scans, we could look through Henry's scalp and skull to see his brain" (80). It would be more accurate to say that MRI technology enabled Corkin and her colleagues to create images of his brain through a complex algorithmic and visualization process, but Corkin's description creates a more arresting image of physical intimacy. As a narrator, she feels for him, as a person and as a subject whose willingness to undergo the ritual of medical and cognitive evaluation became central to the evolution of memory research in the twentieth century.

Corkin admires Molaison's intellectual "acumen"-demonstrated through the cognitive testing-and asserts that "The demonstration that Henry's memory could come to a standstill while his intelligence remained intact indicates that the capacity to form new memories is separate from overall intelligence" (78). Molaison enabled Corkin and her colleagues to contribute to a paradigm shift in memory research-toward an understanding of both its distributed physiology and its imbrication with sensory, cognitive, and affective systems in the brain:

The roots of memory formation are planted in our sensory organs as collections of separate threads. If we focus on our environment at this very moment, we realize that we are receiving different kinds of information simultaneously through our eyes, ears, nose, mouth, and skin.... The process of laying down a memory requires back and forth communication between our hippocampus and the areas distributed throughout the cortex where sensory information was first perceived. During this interaction the hippocampus organizes the cortical components of a memory so they are available for us as a whole memory and not a bunch of disconnected fragments. Together these traces contain a rich representation of our experiences. (Corkin 81)

Corkin describes the brain as a representational organ, synaptic networks creating both experience and our memories of it. When she and her colleagues find gaps in his hippocampus (as well as severe damage to his cerebellum, caused by medication for his seizures, rather than his surgery), they draw the pragmatic conclusion that these gaps explain why his brain doesn't generate the "rich representation of our experiences" they understand as memory.

Shulman turns to the history of memory research as she struggles to adapt to her husband Scott's amnesia-but in contrast to Corkin, she emphasizes the explanatory gap between brain physiology and subjective experience. Shulman summarizes the consensus in memory research: "Science has firmly established that memory is 
unstable and unreliable, that whenever you summon up a recollection of the past you are liable to change it slightly until, with the passage of time, it may no longer represent what actually happened" (11). Later, she elaborates, "since memories of different kinds of things (colors, numbers, music, places, names, among many others) are 'stored' in different specific areas of the brain and can be altered over time the generalized concepts of long-term and short-term memory are no more than theoretical constructs.... Cognitive scientists... divide memory into ever finer categories"-including sensory memory, semantic memory, episodic memory, and associative memory (140). But whereas Corkin emphasizes the considerable strides of memory research, Shulman grapples with what science can't tell her about Scott's experience:

Mapping of brain activity through advanced imaging techniques has established that the hippocampi, important structures in the temporal lobes are critical to the process of making memories stick.... But how memories are actually laid down and stored in the brain-what the process of becoming electrochemically hardwired consists of-remains a mystery" (140).

That mystery complicates her relationship with Scott-and informs her moving account of contemplating his death and doing what she can to honor his wishes. "Death -his, mine-suddenly seems sweet," she writes. "I keep hearing in my ears Scott's answer to the trauma doctor's candid question about whether he'd want to be kept alive if he couldn't continue to live independently: No, I don't think so. No. I read over the start words of our living wills: If I am irreversibly demented.... withhold all treatments or interventions which are not designed solely for my comfort" (146). Despite the clarity of Scott's "No" and the words of the living will, Shulman's book documents her decision to help him live with her, in a complex relationship of interdependence. They have conversations, eat together, and renew their sexual relationship. After a lengthy meditation on the meaning of this renewal-and the history of their sex lives-Shulman asserts, "My passionate purpose is to stimulate his brain and help him heal, while for him, unable for the most part to lay down new memories, whatever we do must be for its own sake. 'Living in the moment' is not a goal for him, but the only available option, the default position" (74). The physical intimacy of husband and wife is, of course, very different from that of researcher and subject. But Shulman's story overlaps with Corkin's in the sense that a physical, affective relationship that does not involve shared memory remains a vital one. For Shulman, "to love what is" means living with Scott's brain, helping him heal, despite the mysteries of the explanatory gap that haunt her.

Ultimately, the intimacy of the relationships they recount enables Corkin and Shulman to identify the expression of personal qualities that don't require conventional autobiographical memory. While Henry may have "lived in a permanent present tense," "despite his amnesia, Henry had a sense of self." Corkin describes this sense of self as "skewed, weighted heavily toward his general knowledge of the world, his family, and himself before 1953." Corkin acknowledges that "memory is an essential component of everything we do" and that "we need memory to survive" (xii, xvii). The distinction is subtle, but crucial. Memory is central, but it's not all there is to identity. The startling personality changes Shulman observes in her husband lead her to a similar conclusion: "The dignified, courtly man I love has emerged from his enforced silence a loquacious stranger-sometimes a clown, full of wild flights of wordplay that keep Heather and Norm and me howling with laughter, sometimes a garrulous, nonsensical, even dirty old man hitting on the nurses" (33). 
26 Living with Scott prompts Shulman to ask, "Can his injury have transformed his very self, stricken deep into his identity? Or revealed a buried self I never knew?" Eventually, Shulman answers her own question: "But to those of us who know him well, it's clear that underneath it's still Scott, shaky but intact, the tall, sweet, blue-eyed guy who loves-has always loved-traveling" $(33,137-38$.) In both cases, the devastation of amnesia is characterized by a loss of autonomy and a fleeting awareness of that loss that comes with the cognitive dissonance of living with memories of a distant pass while trying to navigate the present. Within the dissonance, Corkin and Shulman recognize enduring aspects of identity-Molaison's generosity, Scott's courtliness. That recognition is instructive: An amnesiac's intimates have the capacity to mitigate the isolation and suffering that come with severe memory loss, shaping social relationships that offer continuous opportunities for social interactions that validate the aspects of identity that endure for the particular amnesiac in question. Both writers emphasize a doctrine of contemporary memory research: the fact that memory is not a single phenomenon; its physiology is distributed and its phenomenology variable. Of course, the same is true of selfhood. If neither memory nor identity is singular, it makes little sense to equate them. The equation is complicated further by the role of forgetting in the making of memory.

\section{Amnesia and Experimental Fiction}

Intimacy, both personal and social, is also central in both The Man Who Walked Away and The Buried Giant-intimacy with readers and intimacy among characters. Casey and Ishiguro build fictional worlds to explore a counterintuitive proposition, that in particular, extreme circumstances, amnesia may be preferable to remembering. With Casey, amnesia may be preferable to reliving past trauma, and it may enable novel perceptual experiences, allowing her protagonist to live mostly in lyrical present. With Ishiguro, collective amnesia may be preferable to remembering political divides that lead to war and slaughter, and, more personally, may allow the couple at the story's center to forget past transgressions and traumas that threaten their relationship. Both are experimental historical fictions with stylized approaches to undoing the memoryidentity equation. In Memory in Literature: From Rousseau to Neuroscience (2003), Suzanne Nalbantian observes that literary texts and neuroscientific research both portray a dynamic relationship between memory and forgetting:

The topic of memory attrition brings attention to the phenomenon of 'oubli,' or biological forgetting. Some recent researchers have studied the consolidation of memory in sleep, performed by the hippocampus. Others have observed that the elimination of certain ordinary trivia can provide for acquisition of long-term memory. On the other hand, the redundancy resulting from the coexistence of several memory systems can account for the reversibility of forgetting. It is also true that forgetting can provide a compensation for surcharge which can arise from an overload of short-term memory. (147-48)

Nalbantian cites Mallarmé and Borges among writers who have explored the dynamic between memory and identity. Casey and Ishiguro are certainly writing in this tradition, but neither is interested in generalizing about memory. Instead, they write intensely subjective accounts of fictional characters whose amnesia produces exceptional forms of identity. While they do emphasize the social and cultural 
implications of their amnesiacs' unusual minds, they don't reflect much on the physiology of memory per se, emphasizing the phenomenology of memory instead.

While they play with the idea that forgetting may be preferable to remembering, Casey and Ishiguro explore the suffering that comes with amnesia with a great deal of sensory, emotional, and stylistic, and care. Their distinctive and highly original forms of narration follow directly from their ambivalence about retrieving lost memory. Casey's novel is a fictionalization of a nineteenth-century case history about fugueur Albert Dadas, who trekked vast swathes of Europe in fugue states, finding himself in far-flung towns with little or no memory of how he'd gotten there. Ishiguro's novel dramatizes the quest of an Anglo-Saxon couple whose village is one of many whose inhabitants' memories are obscured by a mist that turns out to be the breath of an enchanted dragon. Both novels tell stories about ambivalent quests to restore memory. In Casey's novel, Dadas's amnesia is portrayed as intrinsic to his identity. Who would he be if his memory were restored? In Ishiguro's, collective memory loss frees citizens from histories of personal trauma and ensures peace by erasing everybody's recollection of longstanding tribal feuds. They are both third person narratives that mingle omniscience with a free indirect speech, offering sentence level mimesis designed to represent the subjectivity of amnesiac experience. They are bewilderingly beautiful novels that challenge readers to consider novel hypotheses.

Casey's Albert finds himself in an asylum, under the care of The Doctor, whose "moral medicine" involves a holistic approach to healing. The setting is designed to afford him the identity that has eluded him as he's been wandering the countryside. In sessions with The Doctor, Albert experiences flashes of memory: “'In Saint-Étienne, I remember lying in a hospital with a cold compress on my head, given quinine sulfate to cure a toothache,' Albert offered yesterday as it rose up into the light of his memory-the cold compress, the quinine, the toothache, and Saint-Étienne disappeared" (135). These memories are largely sensory, and they return him to moments when the urge to roam overcomes him, as when he walks "through a town whose name he never learned, filled with the delicate fragrance of the rosewater manufactured there, walking until the earth's tremor rumbled through his feet and up his shins, until his bones expanded, until his blood circulated astonishment, until, finally, there it was, the urge to walk, and he was lifted into oblivion" (135).The Doctor comes to recognize the value Albert finds in the astonishment and oblivion that characterize his fugue states. They become his identity. Describing their sessions, the narrator observes, "Albert is a house, and each day the Doctor discovers another door, but sometimes when the Doctor turns the knob, gives it a gentle push, there is a room so full of shame that Albert cannot bear to go inside." Through their sessions, they find Albert's "ragged memory." He fell out of a tree when he was a child and injured his skull. A more conventional nineteenthcentury physician-say Charcot or Freud-might tag this memory as a primal scene and identify it as the cause of Albert's fugue states. But Casey refuses to endorse straightforward cause-effect relations between Albert's past and his symptoms. Her narrator maintains a stance that emanates from the subjective experience of the patient, for whom the symptoms-the amnesia, the walking, the attunement to a radical present-are a way of life. Albert finds glimpses of "his lost life not lost at all, though there are parts of it he wishes would stay lost" $(204,208)$. The novel begins and ends in ambivalence. Albert's fugue states make for a tenuous life, but he values them nonetheless. He will continue to walk, whatever the consequences. 
Casey's narration style emphasizes Albert's memories as a kind of collaboration between Albert and the Doctor. Her third-person narrator is doubly focalized-and intimately so-weaving the perspectives of doctor and patient so that they are difficult to differentiate. Casey's narrator wanders in and out of her character's mental lives, often blending them and occasionally offering explicit descriptions of the technique. Albert's arrival at the asylum, for example, initiates a collective blending of identity: "Since the arrival of the new patient, the universe has shifted slightly. The simple vase of the asylum is not so simple after all. The arrival of someone new, and suddenly everyone is sloshing over its edges" (183). The sloshing is particularly pronounced in the relationship between Albert and the Doctor-and apparent during their hypnosis sessions:

When his eyes flutter open, he feels as though he will disappear into the Doctor's eyes.

Perhaps because the Doctor says, 'You are disappearing.'

And then the room disappears too.

Shh, Albert.

The Doctor's voice is a tabletop, its surface expanding. Albert could lay his whole body there.

Shh, Albert. The Doctor's hand strokes the top of Albert's head; it smells of pomade and sausage. Your eyelids are warm. He flutters them, and it's true. They are getting warmer. Everything is warm: the Doctor's breath on Albert's face; his swirling fingertips; this body he's carried with him over the years, or years and years and, oh, he has been so tired. His body grows warmer; it burns off all those lost years. Where did they go? It doesn't matter. When his eyes flutter open again, the Doctor's eyes say: I know everything you have forgotten.

There were times when, not knowing how he got there, Albert would discover himself walking at night. The clang of church bells, a trickle from a nearby stream, the texture of the road underfoot his only guides as he stumbled into woodpiles; on one occasion, he fell over the side of a bridge. The Doctor's eyes are like the sheep Albert once saw up ahead, tufts of white in the pitch-dark night, the time he discovered himself crawling out of a coal bin: This way, this way. (194-95)

Casey dramatizes her characters' relational identities explicitly when she writes that Albert might "disappear into the Doctor's eyes" or that the Doctor "will remember everything." She does so implicitly in moments when it seems that a thought, perspective, or feeling belongs to both characters at once, as in "Shh, Albert." Is this the Doctor expressing his wish for Albert to achieve a hypnotic state, or Albert willing himself to cooperate? Or both? When the narrator asserts, "there were times when, not knowing how he got there, Albert would discover himself walking at night," the implication is that these memories are the product of the hypnosis. They're narrated outside time, though. They belong as much to Albert while he was hypnotized as they do to the Doctor reflecting on them both during and after-remembering what Albert has forgotten. It's the relationship that tempts Albert to remain at the asylum. Despite his urge to wander and forget, he wills himself to remain, to build memories and relationships. But his will, it turns out, is not enough to keep him there.

Ishiguro's protagonists, Axl and Beatrice, wander too-but in search of memory, even when they are ambivalent about its power. They are a long-married Briton couple who go walking in search of their adult son. Throughout, they are ambivalent about regaining memories of their relationship, their region's history, and their son's whereabouts. In one typical passage, Axl ruminates on this ambivalence: "Should Querig really die and the mist begins to clear. Should memories return, and among 
them of times I disappointed you. Or yet of dark deeds I may once have done to make you look at me and see no longer the man you do now. Promise me this at least. Promise, princess, you'll not forget what you feel in your heart for me at this moment. For what good's a memory's returning from the mist if it's only to push away another?" (251-52). Along the way, Axl and Beatrice acquire traveling companions-Wystan and Edwin (warriors named for Wystan Auden and Edwin Robinson, modernist poets known for their interest in medieval culture) and Sir Gawain (a character well known as a Knight in Arthur's court and as the protagonist of the medieval romance Sir Gawain and the Green Knight). They join the warriors in a quest to slay the dragon, Querig, whose breath creates the amnesiac mist. As a collective, the group relationships afford each individual the opportunity to collaborate on their aims, goals, and reflections-in short, their agency. They collaborate in acts of remembrance and in the making of relational identities. Their lives and quest gain meaning only through this collaboration. In fact, they would never survive their journey if not for each other.

As they begin to understand the origins of their collective amnesia, they debate its pros and cons. With their memories regained, Axl and Beatrice might find their son and recover their shared history, but they might also learn something they don't want to know. In fact, their son is dead, and their marriage was not always peaceful. The risks are not limited to the personal. With memory comes history, and with history comes the potential for war. Gawain reveals himself the protector of the dragon-and therefore the keeper of amnesia: "Without this she-dragon's breath, would peace ever have come? Look how we live now, sir! old foes as cousins, village by village.... Think, sir, once that breath should cease, what might be awoken across this land even after these years!"' (278). The novel ends with the dragon slain, but the mist not yet evaporated fully. Axl and Beatrice begin to realize their son is dead, that their quest has been for their own deaths. The implication is that Gawain's desire to maintain collective amnesia is a fantasy. We must live with memory, but we must also recognize that memory brings personal pain and political strife. Ishiguro writes to engage readers in some reflection about memory's dark side.

Though Ishiguro's mist causes collective amnesia, Axl and Beatrice become representatives of its personal stakes. Their relationship is a vehicle for exploring the personal cost of remembering. As Beatrice tells Axl, "'take my hand and help me keep my courage. For I'm thinking now I'm the one to fear most the mist's clearing, not you. I stood beside those stones just now and it came to me there were dark things I did to you once, husband. Feel how this hand trembles in yours to think they may be returned to us! What will you say to me then? Will you turn away and leave me on this bleak hill?"' (282). Ishiguro is well known for narrative ambiguity, and plotting memory's idiosyncracies, in novels like The Remains of the Day (1989), The Unconsoled (1995), and When We Were Orphans (2000). It's not clear if the rock is a retrieval cue, enabling Beatrice's terrifying flash of memory, or if it's an incidental part of the landscape. It is clear that the personal cost of memory is related, again, to intimacy. With their trembling hands clasped, wife and husband share an affective response to their shared history, however dark or troubled. Beatrice is worried about the implications of the past for the future. If he remembers the "dark things" she may have done, will he abandon her? But the novel ends with the revelation that all along, they'd both been traveling toward death-represented as an island. Their quest for their son was a quest to join him there. The poignancy of the narrative relies on the recognition that shared memory is often painful-and that the pain is constitutive when it comes to relational 
identity. As a thought experiment, the novel is a provocation to readers to recognize this. Amnesia, memory's absence, becomes a vehicle for meditating on the cost of remembering as well as the imaginative reconstructions of the past involved in doing so.

\section{Revising Buñuel}

Psychologist Karen Brandt argues that "the act of forgetting is a most necessary affair." In her essay, "Directed Forgetting," a synthesis of memory research focused on the role of forgetting (both unintentionally and intentionally), she concludes, "Without the ability to forget, our minds would be cluttered with needless and unwanted thoughts and facts. The research on unintentional forgetting demonstrates that we forget the details about learned material rather quickly and instead retain the gist of our knowledge. However, this fact does not appear to impede our everyday lives; not many of us remember the details we learned in the Highway code to pass our driving test and yet we are able to drive successfully without impediment on a daily basis. Furthermore, unintentional forgetting actually benefits us by eliminating memories that are no longer relevant to us, including those that could impede our ability to function" (282). There is a common-sense element to Brandt's account. If we remembered everything we experienced, we'd have a hard time getting through a day. But who's to say what's "no longer relevant to a given person." In some ways, what we remember determines what's relevant.

For the past two decades, Cristina Alberini, a neuroscientist and trained psychoanalyst, has been conducting research that's extending memory theory's edges in multiple directions-research that ranges from environment and phenomenology to genes and proteins. Today, most people with even a passing interest in memory will have a sense that it has something to do with synaptic activity. Many will have read or heard that the hippocampus is involved in memory consolidation-or the making of long-term memories. Most will know very little about how gene expression or protein synthesis shape memory. Alberini doesn't claim to connect all these dots, but she is making them the focus of careful examination. In one article, she describes gene transcription as a "a highly regulated process that involves the combined interaction of chromatin and many other proteins sophisticated response to multiple environmental conditions," including learning and development, a child's bonding with its mother, or stress ("Transcription Factors in Long-Term Memory and Synaptic Plasticity" 121, 139). Another article, co-authored with Charles Finsterwald, begins with experience-stress -to make an argument for the molecular mechanisms that govern how and why certain degrees of stress enhance memory consolidation while others impair it. Alberini and Finsterwald explain how glucocorticoids, a class of steroid hormone, influence "the consolidation of several types of hippocampal-dependent memories, including spatial and contextual memories in rodents and declarative memory in humans." Alberini and her colleagues have identified synaptic pathways whose activities are influenced by glucocorticoids that circulate in response to moderate stress. Conversely, they observe that "although it is known that glucocorticoids and GRs also play a critical role in memory impairments following chronic stress or traumatic experience, the underlying molecular mechanisms have not yet been identified." The influence of these hormones may involve "rapid non-genomic" and 
"long-term genomic" changes (Finsterwald and Alberini 18, 25). Hormones circulate in response to experience, and the results may be short- or long-term changes in the organism.

These are articles published in specialized journals, notable for their expansive but measured rhetorical approach to linking the physiology and phenomenology of memory. Alberini's psychoanalytic training is detectable in her representation of dynamic relations between experience and physiology. She is technical about the physiology, but never reductive about its implications. While she doesn't overstate the human implications of animal research and acknowledges epistemological implications of her research, she consistently makes a case for connecting those dots between phenomenology and physiology. Much contemporary memory theory focuses at the level of the neuron. Alberini's focus is both smaller and larger, charting an uncertain course that ranges through proteins and genes, neurons and neural systems, and the human experiences of living with bodies made of these components. In that sense, Alberini's work investigates some of the same questions as literary amnesia narratives - going both deeper and wider than Buñuel could have imagined when he equated memory and identity.

Alberini's article on memory enhancement (co-authored with Dillon Chen) illustrates the stakes of understanding the fine-grained details of memory's physiology. Alberini notes that a range of memory enhancing drugs and cognitive activities have been developed in recent years, and while she endorses their therapeutic possibilities, she also warns that "Given that memory formation is such a dynamic process, gaining a more complete understanding of the anatomical and temporal dynamics of the molecular and systems changes required after learning and retrieval to consolidate memories will enable researchers to develop the most specific and efficacious memory enhancers" (Alberini and Chen 281). Negative consequences of enhancing memory might include the indirect enhancement of painful memories or memory "dysregulation"-at least partly because, as Alberini has been known to observe, forgetting is an integral part of remembering. Sometime in the future, it may be possible that such enhancements might help people like Henry Molaison or Shulman's husband Scott, but that will only be possible if Alberini's dots get connected, so that we may avoid some of the nightmares fictional characters like Casey's Albert or Ishiguro's Beatrice and Axl associate with remembering. Like Alberini's research, all of these narratives envision memory outside straightforward teleological models-emphasizing relations between experience and physiology and subtle dynamics between remembering and forgetting that make memory functional.

None of these writers is suggesting that amnesia is preferable to a normally functioning memory. Instead, they respond to advances in memory research and experiment with narrative approaches that revise Buñuel's memory-identity equation: "Life without memory is no life at all... Our memory is our coherence, our reason, our feeling, even our action. Without it, we are nothing." Revising Buñuel's equation, they ask readers to consider a question that follows from the research: If identity is comprised of overdetermined relations between physiology, culture, and history, if life without memory doesn't make a person "nothing," what does it do? How might we learn more about such questions from examining the subjective experience of amnesiacs through narrative? How might we respond to memory loss in ways that enable and respect the identity of the people in question? In their nonfiction, Sacks, Corkin, and Shulman 
emphasize the stakes of such questions for people living with various forms of amnesia. They offer concrete personal and clinical practices for creating environments and relationships that enable people with severe memory loss to engage in intimate relationships and to express their identities.

In their fiction, Casey and Ishiguro explore the temptation of forgetting when their characters find their realities too difficult to live with. They invite readers to consider the idea that there may be solace in amnesia and menace in memory. But these are not texts with a thesis. Albert Dadas may experience relief from trauma and the wonder of a lyrical perceptual experience-what Corkin calls a permanent present tense-but he is also terrified, haunted, and in danger. He comes close to establishing a community of meaningful and even restorative relationships in the asylum, but he doesn't sustain them. Axl and Beatrice nourish their intimacy despite-or even because of the mist that clouds their memories-but they are compelled to endure a brutal quest to retrieve those memories. They remember the loss of their son and the animosities that fueled war during their lifetimes.

As they experiment with form, Casey and Ishiguro ask readers to contemplate subtleties often overlooked in cultural conversations about memory. For one, as the research shows, memory relies on forgetting as much as remembering in order to function. In addition, in a world where so many people experience or witness trauma and violence, the temptation to forget is worth taking seriously and shouldn't be dismissed casually as denial. In Nobel speech, Ishiguro reflects on the evolution of his formal exploration of memory in his novels,

I'd often written about such individuals struggling between forgetting and remembering. But in the future, what I really wished to do was to write a story about how a nation or a community faced these same questions. Does a nation remember and forget in much the same way as an individual does? Or are there important differences? What exactly are the memories of a nation? Where are they kept? How are they shaped and controlled? Are there times when forgetting is the only way to stop cycles of violence, or to stop a society disintegrating into chaos or war? On the other hand, can stable, free nations really be built on foundations of willful amnesia and frustrated justice? ("My Twentieth-Century Evening-and Other Breakthroughs")

These are the questions The Buried Giant explores, experimenting with formal techniques that expand those of Ishiguro's previous works. Axl and Beatrice are "struggling between forgetting and remembering" in personal terms, but they're also doing it in a collective cultural context. The struggle becomes a metaphor, whereby Ishiguro explores the personal challenges of living through painful political times, including, as he mentions in his speech, the atrocities of World War II and the rise of far-right nationalisms in our current time. In social and political terms, Casey's novel is more focused on medical ethics. Like Ishiguro, though, she reflects on the formal challenge of writing about struggles with memory and forgetting-in particular, about Albert Dadas, a character she created in homage to the historical man who lived and suffered:

The thing that moved me so much about the real Albert Dadas was the way he seemed to both yearn for the walking and be wrecked by it. Again, my interpretation, and one that became central in creating the conflict for my character. There's his desire to be astonished, to be swept up in the ecstatic state of walking, and then there's the fact that he has no control over it. The urge overcomes him, but then it ends just as suddenly and he's utterly lost again. He's at 
its mercy, and this is what makes him so unhappy. (Tougaw, "The Man Who Walked

Away: A Conversation with Novelist Maud Casey")

In literary terms, Casey is interested in Dadas's capacity for astonishment, made possible by the constant lyrical present he lives in. Like Ishiguro, though, she recognizes the costs involved. Both writers are interested in excavating something positive from tragic scenarios-in ways that resonate with the pragmatic approaches that Shulman, Corkin, and Sacks adopt to enhance the lives of the amnesiacs they write about. All these texts unfold in ways that remind us that memory and forgetting are integral to each other. Contemporary memory research compels investigation about the entanglement of physiology, memory, and identity-and the countless ways this entanglement shapes individual experience and social structures. These literary texts remind us how important the dynamic between remembering and forgetting will be to future research.

\section{BIBLIOGRAPHY}

Alberini, Cristina M. "Transcription Factors in Long-Term Memory and Synaptic Plasticity." Physiological Reviews, vol. 89, no. 1, January 2009, pp. 121-145.

Alberini, Cristina M., and Dillon Y. Chen. "Memory Enhancement: Consolidation, Reconsolidation and Insulin-like Growth Factor 2." Trends in Neurosciences, vol. 35, no. 5, May 2012, pp. 274-283.

Lethem, Jonathan, editor. The Vintage Book of Amnesia: An Anthology of Writing on the Subject of Memory Loss. Vintage, 2000.

Karen Brandt, "Directed Forgetting." Memory in the Twenty-First Century: New Critical Perspectives from the Arts, Humanities, and Sciences, edited by Sebastian Groes, Palgrave Macmillan, 2016.

Buñuel, Luis. My Last Sigh: The Autobiography of Luis Bunuel. Reprint edition. Vintage, 2013.

Casey, Maud. The Man Who Walked Away: A Novel. Bloomsbury USA, 2014.

Corkin, Suzanne. Permanent Present Tense: The Unforgettable Life of the Amnesic Patient, H. M. Basic Books, 2013.

Finsterwald, Charles, and Cristina M. Alberini. "Stress and Glucocorticoid Receptor-Dependent Mechanisms in Long-Term Memory: From Adaptive Responses to Psychopathologies." Neurobiology of Learning and Memory, vol. 112, July 2014, pp. 17-29.

Ishiguro, Kazuo. The Buried Giant. Vintage, 2016.

---. "My Twentieth-Century Evening-and Other Breakthroughs." Nobel Prize Speech (7 December 2017). https://www.nobelprize.org/prizes/literature/2017/ishiguro/lecture/. Accessed 15 Jan 2021.

Kandel, Eric R. In Search of Memory: The Emergence of a New Science of Mind. W. W. Norton \& Company, 2007.

Nalbantian, Suzanne. Memory in Literature: From Rousseau to Neuroscience. Palgrave Macmillan, 2004. 
Sacks, Oliver. The Man Who Mistook His Wife for a Hat: And Other Clinical Tales. Simon and Schuster, 1985.

---. “The Abyss: Music and Memory.” The New Yorker (17 September 2007).

Schacter, Daniel L. Searching for Memory: The Brain, the Mind, and the Past. Basic Books, 1997.

Shulman, Alix Kates. To Love What Is: A Marriage Transformed. Farrar, Straus and Giroux, 2009.

Tougaw, Jason. The Elusive Brain: Literary Experiments in the Age of Neuroscience. Yale UP, 2018.

---. "The Man Who Walked Away: A Conversation with Novelist Maud Casey." Californica: Portrait of the Artist as an Organism (18 August 2014). http://californica.net/2014/08/18/the-man-whowalked-away-a-conversation-with-novelist-maud-casey/. Accessed 15 Jan 2021.

\section{ABSTRACTS}

Amnesia fictions may be the most abundant precursors to the contemporary neuronovel. A cluster of recent, high-profile fiction and nonfiction amnesia narratives join a rapidly evolving tradition of neuronovels and brain memoirs, drawing on neuroscience to explore philosophical and social questions about the brain, identity, social relations, and history. While these texts vary in the representation of memory, forgetting, and identity, they share some fundamental elements: 1) They portray extreme instances of amnesia in order to explore philosophical and psychology questions about the role of forgetting in memory itself, 2) They offer detailed exploration of elements of identity that remain when memory is lost, and 3) They build worlds around their amnesiac characters, worlds designed to afford them respect, agency, and opportunities to express aspects of their identities that survive their failing memories.

\section{INDEX}

Keywords: Amnesia, Memory, Forgetting, Identity, Neuronovel, Brain Memoir

\section{AUTHOR}

\section{JASON TOUGAW}

Jason Tougaw is Professor of English at Queens College. He is the author of Touching Brains: Literary Experiments in the Age of Neuroscience and Strange Cases: Medical Case Histories and the British Novel. His memoir, The One You Get: Portrait of a Family Organism, earned the Dzanc Books Nonfiction Prize. 